Acta vet. scand. $1961,2,137-150$.

From the medical department for non-ruminants, Royal Veterinary College, Stockholm.

\title{
THE AETIOLOGICAL ROLE OF HEPATITIS CONTAGIOSA CANIS (HCC) IN CHRONIC NEPHRITIS IN DOGS
}

By

\section{F. Persson, S. Persson and M. Sibalin}

Despite the high incidence of chronic nephritis in dogs, especially old dogs, its aetiology has not been made fully clear. In countries where leptospirosis prevails this condition is regarded as the cause of chronic nephritis in a high percentage of cases (Ottosen, 1939; McIntyre and Montgomery, 1952). Another condition that has been considered as a possible causal agent is the canine viral hepatitis, hepatitis contagiosa canis (Hcc). The discoverer of Hcc (Rubarth, 1947) demonstrated inclusion bodies in the glomeruli, which were specific of the disease. Poppensiek and Baker (1951) showed that the virus is excreted via the kidneys, and were able to isolate the virus from the urine of a dog 161 days after experimental induction of infection. These authors, as well as Stünzi and Poppensiek (1953) and Stünzi (1954), in studies on dogs which had recovered from the disease, demonstrated focal or interstitial nephritis which disappeared later on by resolution and absorption, and not by reactive fibrosis. Hartley, in 1958, reports that among 30 dogs with spontaneously developed Hec distinct areas of interstitial nephritis were found in 6. Others (Bloom, 1954; Smith, 1956; Uvarov, 1956) also consider it probable that, aetiologically, Hcc is responsible for some of the cases of nephritis in dogs. But so far this has not been supported by any evidence. In a recently published work Piercy and Sellers (1960) were not able to find any histologically demonstrable changes in the kidney after vaccination with living virus.

Canine infection with leptospira canicola is considered not to occur in Sweden, as it has been impossible to show. Since the 
incidence of nephritis is as high here as in other countries, it would be of value to try to find out whether there exists a relationship between Hcc and chronic nephritis. In spontaneous cases of Hcc we have seen high-degree proteinuria, which has also been reported by others (Coffin and Cabasso, 1953). As the Hec infection is very widely spread, it is probable that during his life-time a dog will be exposed to repeated infection with the virus concerned.

In order to answer the question whether the acute illness due to an infection can give rise to persistent renal damage, a series of dogs inoculated with Hcc virus were studied with respect to the state of the kidneys. To find out whether repeated re-infections would dispose to nephritis a clinical material was also examined for renal changes and the presence of antibodies in the blood-serum to Hcc.

\section{EXPERIMENTAL STUDIES}

Material and methods.

Twenty mongrel dogs were used. Of these, 10 were 5 months old, 6 were 6 months and 4 were 24 months old. Most of the younger dogs were reared strictly isolated. By neutralization tests it was demonstrated that the antibody titre in the serum of all the dogs was $<0.7$. The state of the kidneys was investigated by urinalysis and determination of non-protein-nitrogen in the blood, and by inulin and PAH clearance. The technique used in the renal-clearance determinations and the analytical methods employed for determination of inulin and PAH in blood-plasma and urine have been described in detail in an earlier work ( $\tilde{A} s$ heim, Persson and Persson, 1961). The renal-clearance tests were done under light anaesthesia with pentobarbitone.

Four of the dogs were used as controls, while the other 16 were inoculated with Hcc virus ${ }^{1}$ ). To test the virulence of the virus suspension we used 3 months old puppies which were reared artificially without colostrum and were kept strictly isolated. Two puppies were given intraperitoneally (Rubarth, 1947) $0.3 \mathrm{ml}$ of virus containing 6.1 $\mathrm{TCD}_{50}$, while two were inoculated by conjunctival instillation (Mansi, 1956). One dog was given one drop

1) The virus used was an "SBL" strain, propagated in tissue culture from dog's kidney. It was kindly supplied by Dr. R. Salenstedt of the State Bacteriological Laboratory, Stockholm. 
in each eye, and the other dog one drop in one eye only. Of the two dogs inoculated intraperitoneally both fell ill with typical symptoms of Hcc, and one of them died. The diagnosis of this one was verified at autopsy. Of the dogs inoculated by conjunctival instillation the one which received one drop in one eye only became ill, while the other one did not. To find out whether a lower dose would be sufficient a fifth dog was inoculated intraperitoneally with $1 / 10$ dose. This dog did not fall ill. As a control the dog that had been inoculated by conjunctival instillation and recovered was re-inoculated, this time intraperitoneally with $0.5 \mathrm{ml}$ of virus. It did not became ill, which shows that the conjunctival instillation of the virus had conferred immunity but was not sufficient to produce disease.

On the basis of these experiments the dogs were inoculated intraperitoneally with $0.2 \mathrm{ml}$ of virus containing $6.1 \mathrm{TCD}_{50}$ per $\mathrm{ml}$. Two of the dogs died 6 and 8 days, respectively, after inoculation. The autopsy findings were typical of Hec.

The conditions taken as a criterion of developed disease were - besides a poor general condition - raised temperature, leucopenia, increased levels of serum-transaminase enzymes and the presence of antibodies in the blood. The enzyme activity was determined by the methods described by Wretlind et al. (1959). Glutamic-oxaloacetic transaminase (GOT) and glutamic-pyruvic transaminase (GPT) were estimated by the methods of Reitman and Frankel (1957) and the ornithin-carbamyl-transferase (OCT) by the method of Reichard (1957).

After inoculation specimens of blood and urine were collected every other day until the dogs had recovered. The blood was examined for total leucocyte count and differential count, and for the activity of serum-transaminase enzymes. Usual analysis of urine was done. During the period of convalescence repeated determinations of the antibody titre in serum and examinations for the presence of virus in the urine were carried out. The dogs were killed at different times after inoculation, according to a schedule covering 6 months. Before killing, a second renalclearance test was done. Autopsy was performed with histological examination of the kidneys.

For the histological examination the kidneys were removed immediately after killing. They were treated with different fixation liquids, such as $\mathbf{1 0} \%$ formalin, Bouin's fluid and Helly's fluid. The preparations were stained by van Gieson's method 
(Haematoxylin-picric acid fuchsin), with haemalum-eosin and silver nitrate impregnation by Foot and Foot's modification of Bielschowsky's method ${ }^{1}$ ) and were tested for oxidase reaction by the method of Schultze.

\section{Virological methods.}

Blood was drawn from $V$. cephalica antebrachii immediately after the arrival of the dogs at the clinic. Serum was centrifuged at $2000 \mathrm{rpm}$ for 20 minutes, inactivated at $56^{\circ} \mathrm{C}$ for 30 minutes and stored at $-20^{\circ} \mathrm{C}$.

Tissue cultures were prepared as follows: The kidneys from 1-2 months old puppies kept strictly isolated were removed aseptically. The minced cortex was trypsinized by the method of Youngner (1954). The trypsinized kidney-cells were grown at $37^{\circ} \mathrm{C}$ on Hanks' balanced salt solution (Hanks' BSS) with 0.5 lactalbumin hydrolysate and $5 \%$ calf's serum in $8 \times 1 \mathrm{~cm}$ test tubes and Roux bottles. The maintenance medium consisted of Hanks' BSS with $0.5 \%$ lactalbumin hydrolysate. To all the media were added 100 units of penicillin and $100 \mu \mathrm{g}$ of streptomycin per $\mathrm{ml}$ of medium. The tissue culture (t. c.) tubes were used for tests after complete development of cell monolayer, usually after an incubation period of $3-5$ days. Maintenance medium contained no serum.

Virus titrations and neutralization tests: For cultivation of virus tissue culture in Roux bottles containing $100 \mathrm{ml}$ of Hanks' BSS was used. Serial tenfold dilutions of virus suspension were prepared in phosphate-buffered saline (PBS) and each dilution was inoculated into $5 \mathrm{t}$. c. tubes using an inoculum of $0.10 \mathrm{ml}$ per tube. The reading of the $t$. c. tubes for cytopathogenic effect was done every 3 days and final reading 5 days after complete cell-degeneration in virus control tubes. The titre values are expressed as 50 per cent t.c. doses $\left(\mathrm{TCD}_{50}\right)$ per $\mathrm{ml}$ and determined by the method of Kärber (1931).

Neutralization tests were performed using twofold dilutions of serum in PBS. Each serum dilution was mixed with an equal volume of virus suspension containing approximately $100 \mathbf{T C D}_{50} /$ $0.10 \mathrm{ml}$. This calculation was based on average titres. The virus-

1) The autopsies and the histopathological examinations were carried out at the Department of Pathology, the Royal Veterinary College. 
serum mixture was incubated in a waterbath at $37^{\circ} \mathrm{C}$ for one hour and thereafter kept at $+4^{\circ} \mathrm{C}$ until required. From each serum dilution $3-5$ t. c. tubes were inoculated with $0.20 \mathrm{ml}$ of serum-virus mixture and kept in a stationary position. Positive and negative serum controls and virus titration were always performed simultaneously with each test. Final readings were done 5 days after complete degeneration of cells in negative serum control tubes. The neutralization titre is, in accordance with Kärber's principle, given as the reciprocal of the serum dilution at the neutralizing end point.

Results.

In Table 1 are listed those data that show the result of inoculation with Hec virus in the inoculated surviving dogs.

Table 1 .

Result of inoculation with Hec virus.

\begin{tabular}{|c|c|c|c|c|c|}
\hline Dog & $\begin{array}{c}\text { Age } \\
\text { months }\end{array}$ & $\begin{array}{c}\text { + indicates } \\
\text { dogs reared } \\
\text { in strict } \\
\text { isolation }\end{array}$ & $\begin{array}{c}\text { Total number } \\
\text { of leucocytes } \\
\text { per c. mm. } \\
\text { Minimum value }\end{array}$ & $\begin{array}{c}\text { Temperature } \\
{ }^{\circ} \mathrm{C} \\
\text { Maximum } \\
\text { value }\end{array}$ & $\begin{array}{c}\text { Transaminase } \\
\text { rise }(+) \\
\text { No rise }(-)\end{array}$ \\
\hline 1 & 5 & + & 2100 & $40.5^{\circ}$ & + \\
\hline 2 & 6 & - & 3100 & $40.2^{\circ}$ & - \\
\hline 3 & 5 & + & 2700 & $40.8^{\circ}$ & + \\
\hline 4 & 6 & - & 2500 & $40.8^{\circ}$ & + \\
\hline 5 & 6 & - & 6300 & $40.5^{\circ}$ & + \\
\hline 6 & 5 & + & 2400 & $41.2^{\circ}$ & + \\
\hline 7 & 24 & - & 8100 & $39.0^{\circ}$ & - \\
\hline 8 & 6 & - & 4700 & $40.3^{\circ}$ & - \\
\hline 9 & 6 & - & 8800 & $40.2^{\circ}$ & + \\
\hline 10 & 24 & - & 3000 & $39.1^{\circ}$ & - \\
\hline 11 & 5 & + & 2700 & $40.5^{\circ}$ & + \\
\hline 12 & 5 & + & 4600 & $40.8^{\circ}$ & + \\
\hline 13 & 5 & + & 2800 & $40.7^{\circ}$ & + \\
\hline 14 & 24 & - & 2900 & $39.3^{\circ}$ & - \\
\hline
\end{tabular}

In assessing the activity of transaminase enzymes the normal values published elsewhere were used as material for comparison. In normal dogs the mean values are

for GOT $17.2 \pm 0.93$ s.e.m. enzyme units for 52 degrees of freedom for OCT $2.2 \pm 0.27$ s.e.m. " $\quad$ " $45 \quad$, , " for GPT $10.3 \pm 0.92$ s.e.m. $\quad, \quad, \quad, 21 \quad, \quad, \quad$, 
The morbid picture of the different dogs showed great uniformity, even with regard to the laboratory tests. As a model may serve dog no. 1, which was fully investigated clinically, the result being shown in Fig. 1. The studies of the antibody titre in serum and the persistence of virus in the urine covered different lengths of time in different dogs. The results are seen in Table 2.

T a b l e 2.

Antibody titre and virus isolation from urine after inoculation.

\begin{tabular}{|c|c|c|c|c|c|c|c|c|c|}
\hline \multirow[t]{2}{*}{ Dog } & \multicolumn{6}{|c|}{$\begin{array}{l}\text { Neg. log. of tissue culture neutralization } \\
\text { end points of serum. } \\
\text { Number of days after inoculation. }\end{array}$} & \multicolumn{3}{|c|}{$\begin{array}{l}\text { Re-isolation of virus } \\
\text { Number of days after } \\
\text { inoculation. }\end{array}$} \\
\hline & 25 & 40 & 60 & 103 & 137 & 153 & 25 & 103 & 153 \\
\hline 1 & 3.0 & & & & & & + & & \\
\hline 2 & $>3.1$ & & & & & & + & & \\
\hline 3 & & 2.9 & $>3.1$ & & & & + & & \\
\hline 4 & & 3.0 & $>3.1$ & & & & + & & \\
\hline 5 & & 2.6 & $>3.1$ & & & & + & & \\
\hline 6 & & 3.0 & $>3.1$ & $>3.1$ & & & + & - & \\
\hline 7 & & 2.6 & 2.5 & 1.7 & & & + & + & \\
\hline 8 & & 3.0 & $>3.1$ & $>3.1$ & & & + & - & \\
\hline 9 & & 3.0 & $>3.1$ & $>3.1$ & & & + & + & - \\
\hline 10 & & 2.9 & $>3.1$ & $>3.1$ & 2.2 & & + & - & \\
\hline 11 & & 2.7 & 2.5 & $>3.1$ & & 2.9 & + & + & - \\
\hline 12 & & $>3.1$ & 2.7 & $>3.1$ & & 3.1 & + & + & - \\
\hline 13 & & 2.7 & $>3.1$ & $>3.1$ & & $>3.1$ & + & + & - \\
\hline 14 & & 2.7 & $>3.1$ & 2.6 & & 2.6 & + & + & - \\
\hline
\end{tabular}

The clinical investigation of the state of the kidneys comprised urine examinations, and inulin and $\mathrm{PAH}$ clearance; the latter was carried out before inoculation with virus and before killing. In all the dogs, even in those which reacted only with leucopenia, a moderate proteinuria arose. This was not seen until one day or two after the temperature had begun to rise in reacting dogs and continued for about 14 days. Heller's test was used for estimation of protein, which in spontaneous specimens was throughout present in an amount that could be assessed as $1+$ or, at most, $2+$ in a $3+$ scale. Urine specimens collected at various times of convalescence showed, occasionally, slight proteinuria.

Both inulin and PAH clearance yielded, without exceptions, normal values, and the determinations from the same dog done before and after the disease gave values that did not differ significantly from one another. Normal values for inulin and PAH 

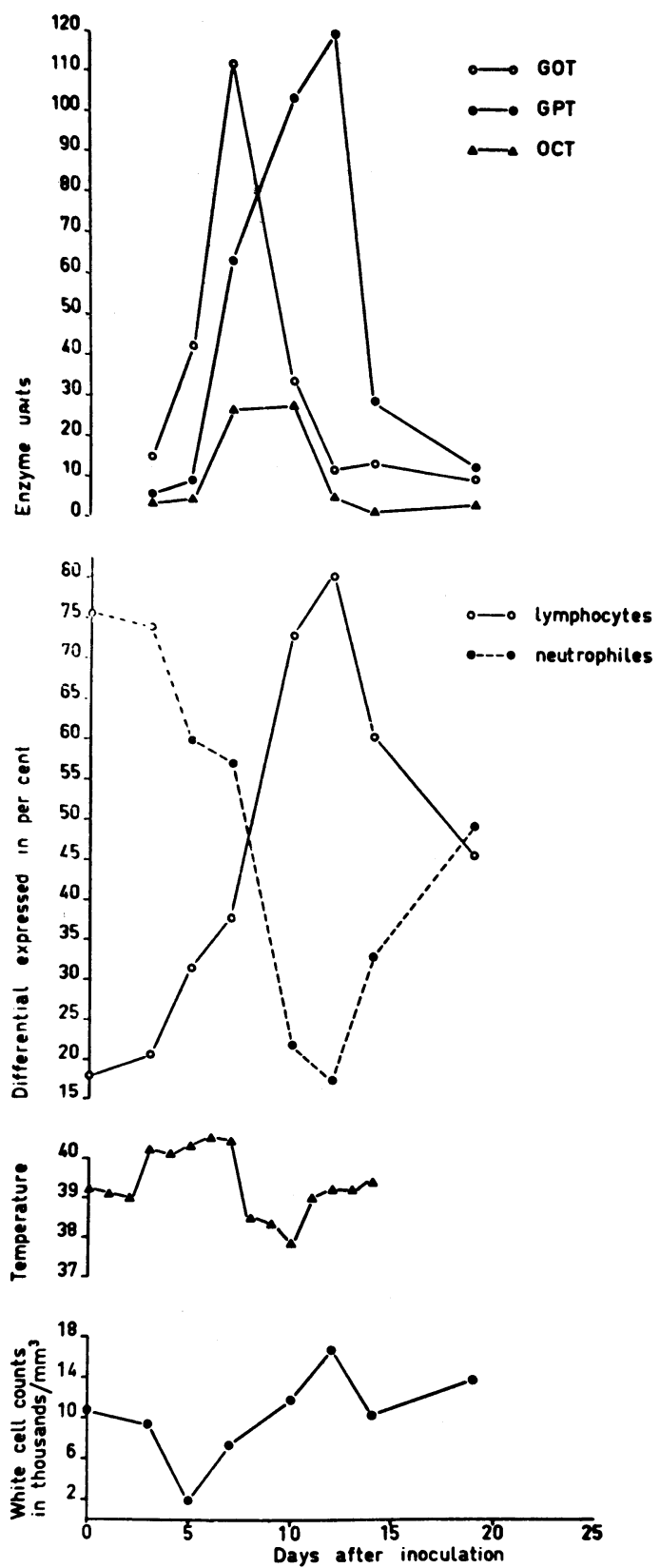

Fig. 1. Experimental infection with canine hepatitis virus in a susceptible puppy. 
clearance in dogs have been reported elsewhere (Åsheim, Persson and Persson).

Autopsy showed in all the dogs normal kidneys both by gross and by histological examination. The time of killing and autopsy will be seen in Table 2. The dogs were killed in connection with the last collection of blood specimens for neutralization tests.

\section{STATISTICAL ANALYSIS OF A CLINICAL MATERIAL}

\section{Material and methods.}

An unbiased investigation was carried out in $154 \mathrm{dogs}$, of which 72 were females and 82 males, which were admitted to the medical department of the Royal Veterinary College in Stockholm in 1959. No selection was done in this material. The clinical examination included the usual procedures. In addition, urine specimens were collected before and after a 24 hour period of no water intake. In the urine analysis our interest was focused on specific weight and on the presence of protein, glucose, blood and sediment. The blood examinations concerned red cell count, white cell count, haemoglobin, haematocrit and non-protein nitrogen. Of the dogs that died during their stay at the clinic or were killed, 33 were subjected to autopsy with histological examination of the kidneys. The presence of antibodies against Hcc was determined by means of neutralization performed on tissue culture.

Results.

Of the 154 examined dogs 42 had renal injuries of varying degree of severity. The clinical diagnosis was made with the aid of the case histories, but the results of examination of urine and non-protein nitrogen in the blood clinched the diagnosis. As a dignostic criterion of renal damage was taken proteinuria in combination with inability to concentration of urine to a specific weight of 1.025 after 24 hours of no water intake. In about half the cases the diagnosis was supported by a raised non-proteinnitrogen level in the blood. Levels exceeding $40 \mathrm{mg}$ per $100 \mathrm{ml}$ were counted as raised values. The fact that moderate rises of non-protein nitrogen can occur in conditions other than renal damage was of course considered.

Among the 42 cases diagnosed as renal damage the diagnosis was verified at autopsy in 11 . 
The age-distribution as regards the serological examination and the number of dogs with kidney damage are seen from Table 3.

Table 3 .

Presence of antibodies and occurrence of renal damage in 154 dogs.

\begin{tabular}{rccrr}
\hline $\begin{array}{c}\text { Age } \\
\text { years }\end{array}$ & $\begin{array}{c}\text { Number of dogs } \\
\text { serologically } \\
\text { positive }\end{array}$ & $\begin{array}{c}\text { Number of dogs } \\
\text { serologically } \\
\text { negative }\end{array}$ & $\begin{array}{c}\text { Number of } \\
\text { dogs with } \\
\text { renal } \\
\text { damage }\end{array}$ & Total \\
\hline$<1$ & $10(45 \%)$ & $12(55 \%)$ & $2(9 \%)$ & 22 \\
$1-4$ & $24(53 \%)$ & $21(47 \%)$ & $12(27 \%)$ & 45 \\
$4-7$ & $28(74 \%)$ & $10(26 \%)$ & $6(16 \%)$ & 38 \\
$7-10$ & $17(65 \%)$ & $9(35 \%)$ & $9(35 \%)$ & 26 \\
$>10$ & $20(87 \%)$ & $3(13 \%)$ & $13(56 \%)$ & 23 \\
\hline & $99(64 \%)$ & $55(36 \%)$ & $42(27 \%)$ & 154 \\
\hline
\end{tabular}

It will be seen from Table 3 that among the older dogs the percentage of serologically positive cases is higher than that among the younger age-groups. The group representing the age up to 1 year can be disregarded in this connection, since it includes the younger dogs which are less exposed to Hcc infection. The values for the other four age-groups were treated by $\chi^{2}$-analysis. This showed that, statistically, the older groups had probably $(0.05>\mathrm{P}>0.02$ for 3 degrees of freedom) a larger number of serologically positive dogs than had the younger groups.

The sex-distribution in the whole material calculated as a percentage is: females $47 \%$, males $53 \%$. Of the dogs with renal damage $55 \%$ were females and $45 \%$ males. Thus, in this material the bitches predominate greatly with respect to renal damage.

The relationship between renal damage and the presence of neutralizing antibodies is seen from Table 4.

Ta b l e 4 .

Relationship between presence of renal damage and neutralizing antibodies against hepatitis contagiosa canis.

\begin{tabular}{lccc}
\hline & $\begin{array}{c}\text { With renal } \\
\text { damage }\end{array}$ & $\begin{array}{c}\text { Without renal } \\
\text { damage }\end{array}$ & Total \\
\hline Seropositive & $31(31 \%)$ & $68(69 \%)$ & 99 \\
Seronegative & $11(20 \%)$ & $44(80 \%)$ & 55 \\
\hline
\end{tabular}


The values in Table 4 were treated by $\chi^{2}$-analysis. This showed that the relationship between the presence of antibodies and renal damage is not significant $(0.2>\mathrm{P}>0.1)$.

To enable a correct assessment of the value of the serological examinations the fact that some dogs were vaccinated with living Hcc virus was taken into consideration. Table 5 records the number of dogs in the different age-groups, which were vaccinated in the year preceding the collection of specimens. It will be seen from the table that, as was expected, most of the newly vaccinated dogs are found in the youngest age-groups. No dog over 5 years of age was vaccinated.

Table 5 .

Number of dogs in different age-groups, vaccinated in the last year before collection of specimens.

\begin{tabular}{|c|c|c|}
\hline $\begin{array}{l}\text { Age } \\
\text { years }\end{array}$ & $\begin{array}{c}\text { Seropositive } \\
\text { (vaccinated in the } \\
\text { last year) }\end{array}$ & $\begin{array}{c}\text { Seronegative } \\
\text { (vaccinated in the } \\
\text { last year) }\end{array}$ \\
\hline$<1$ & $10 \quad(5)$ & $12 \quad(6)$ \\
\hline $1-3$ & $18 \quad(2)$ & 15 \\
\hline$>3$ & $71 \quad$ (1) & $28 \quad(0)$ \\
\hline
\end{tabular}

\section{DISCUSSION}

The available literature contains no definite data on the persistence of neutralizing antibodies after vaccination with living Hcc-virus. Lehnert (1948), after inoculation of living virus, demonstrated the presence of complement-fixing antibodies up to 8 months after inoculation. A study carried out by us, but not yet published, shows good agreement between these two methods. Among 154 tested sera neutralizing antibodies were, however, detected in 21 cases in which the complement-fixation test gave a negative result. Therefore, by rough estimation it seems that 12 months after inoculation could be set as a time limit, after which neutralizing antibodies can no longer be demonstrated, unless re-inoculation has been done. In view of the relatively, small number of dogs which, according to Table 3 , were vaccinated in the year preceding the collection of specimens the importance of this factor in the statistical calculation was disregarded. On the other hand, it is remarkable that such a relatively large number of dogs vaccinated only a few months before the collection of specimens were without neutralizing antibodies. 
Out of the 9 dogs which were vaccinated in the year preceding the collection of specimens but despite this were seronegative, 5 were vaccinated less than 5 months before that date.

A possible explanation of the absence of neutralizing antibodies in blood-serum from these dogs has been given by Larin (1959), who in his paper on "The mechanism of immunity in canine virus hepatitis" demonstrates a spontaneous boostereffect with respect to the antibody titre. According to Larin, after infection there occurs a rise in antibody titre, which soon falls, however, and about 8-12 weeks after inoculation approaches 0 . Without re-inoculation the titre rises again to a higher level, after which it falls slowly.

The fact that so many dogs exhibited a wholly negative antibody titre so soon after vaccination can hardly be explained only on the basis of Larin's observations. It is more probable that for some unknown reason the vaccination has produced unsatisfactory immunity.

The number of serologically positive dogs $(64 \%)$ agrees with that found by Lehnert in 1948. In a corresponding material of dogs from Stockholm he reports that $45 \%$ had complementfixing antibodies to Hcc. Since in our investigation neutralizing antibodies could not be demonstrated by the complement-fixation test in 21 cases, the percentage of positive cases by the complement-fixation method was $51 \%$. Similar figures are also reported from other countries (for instance by Stünzi).

The results of the experimental investigations show that no nephritic changes were induced by inoculation with Hcc virus in previously antibody-free dogs. That the kidneys were to some extent affected because of the inoculation is evident from the proteinuria that throughout occurred for some time after inoculation. This proteinuria must be regarded as a manifestation of reversible nephrosis. An observation of special interest in this connection is that 3 dogs at the age of 2 years did not react either with a temperature rise or with increased activity of transaminase enzymes but exhibited leucopenia and proteinuria. That these dogs did not fall ill with symptoms characteristic of Hcc was probably attributable to the fact that they had earlier been infected with the virus and retained their resistance to the disease but had again become free from antibodies. Larin observed that 7 adult dogs, serologically negative as regards complement-fixing antibodies, did not fall ill after inoculation of antigen but did 
exhibit a marked rise in titre. Considering the large percentage of virus-excreting dogs which constitute an everlasting danger of re-infection, the above phenomenon could, indeed, be perpetually repeated. What role such repeated attacks on the glomeruli with accompanying ischaemic conditions might play in the causation of chronic nephritis, we do not know. It will be seen from Table 3 that among the older dogs the percentage of seropositive cases is higher than among the younger dogs. The explanation of this may be either that the older dogs are more exposed to infection than the younger ones, or that the antibody titre remains longer in the older dogs than in the younger ones. The latter alternative is more probable. However, the duration of the antibody titre would probably not be dependent upon the ages of the dogs but on the fact that these dogs have been exposed to re-infection, perhaps on several occasions. From other virus diseases it is known that a repeated infection gives a titre that is higher and of longer duration than after a primary infection. Table 4 and $\chi^{2}$-analysis of the values, however, show no significant difference in the frequency of renal damage between seropositive and seronegative dogs. It should be remembered that the examination that forms the basis of the statistically treated material is crude. Further studies are necessary to provide an answer to the question whether repeated re-infections with Hcc might be concerned in the causation of nephritis.

In our studies of the leucocytes we found, in contradistinction to the observations by Coffin and Cabasso, a percentage increase of the lymphocytes, which occurred parallel to a decrease of the neutrophil leucocytes (Fig. 1).

The activity of serum-transaminase enzymes rose in a characteristic manner. The slow return to normal values in the case of GPT should be noted.

Virus was recovered from the urine of all the dogs 25 days after inoculation. Of the 9 dogs which after 103 days were examined for persistance of virus in the urine 6 were positive. Out of these 6, 5 were examined after 153 days as well, and were all found to be negative. Thus, roughly half the dogs may be considered to have been virus-excretors up to 4 months after the inoculation. 


\section{REFERENCES}

Bloom, F.: Pathology of the dog and cat. Amer. Vet. Publ. Inc. 1954, p. 90.

Coffin, D. L. and Cabasso, V. J.: Amer. J. vet. Res. 1953, 14, 254.

Hartley, W. J.: New Zealand vet. J. 1958, 6, 111.

Kärber, G.: Arch. exp. Path. Pharmakol. 1931, 162, 480.

Larin, N. M.: Brit. vet. J. 1959, 115, 35.

Lehnert, E.: Skand. Vet.tidskr. 1948, 38, 94.

Mansi, W.: J. comp. Path. 1953, 63, 236.

McIntyre, W. I. M. and Montgomery, G. L.: J. Path. Bact. 1952, 64, 145.

Ottosen, H. E.: 5. Nordiske Veterinærm $\varnothing$ de, København, 1939, p. 1022.

Piercy, S. E. and Sellers, R. F.: Res. vet. Sci. 1960, 1, 84.

Poppensiek, G. C. and Baker, J. A.: Proc. Soc. exp. Biol. Med. 1951, 77, 279.

Reichard, H.: Scand. J. Clin. Lab. Invest. 1957, 9, 311.

Reitman, S. and Frankel, S.: Amer. J. clin. Path. 1957, 28, 56.

Rubarth, S.: Acta path. microbiol. scand. Suppl. 69, 1947.

Smith, K.: Vet. Med. 1956, 51, 163.

Stünzi, H. and Poppensiek, G. C.: Schweiz. Z. Path. Bakt. 1953, 16, 79.

Stünzi, H.: Dtsch. tierärztl. Wschr. 1954, 61, 406.

Uvarov, O.: Vet. Rec. 1956, 68, 1005 and 1033.

Wretlind, B., Orstadius, K. and Lindberg, P.: Zbl. Vet. Med. 1959, 6, 963.

Youngner, J. S.: Proc. Soc. exp. Biol. Med. 1954, 85, 202.

Åsheim, A., Persson, $F$. and Persson, S.: Acta physiol. scandinav. In press.

\section{SUMMARY}

Dogs without antibodies were inoculated with virus of canine hepatitis. The conditions taken as a criterion of developed disease were a rise of temperature, leucopenia and increased activity of serum-transaminase enzymes. The urine was examined for the presence of virus and the antibody titre in blood-serum was determined. Urological studies including inulin and PAH clearance, and histological examination of the kidneys were carried out. No renal changes attributable to the virus inoculation were seen.

A clinical material of 154 dogs was used for a statistical comparison between the presence of antibodies against canine virus hepatitis (Hcc) and renal damage. It was found that $64 \%$ of these dogs had neutralizing antibodies for Hcc, while the percentage of dogs positive by the complement-fixation method was $51 \%$. No significant relationship between the presence of antibodies for Hcc and renal damage was noted. 


\section{ZUSAMMENFASSUNG \\ Etiologische Bedeutung des Hepatitis contagiosa canis (Hcc) bei chronischen nephritiden des Hundes.}

Antikörperfreie Hunde wurden mit Virus der Hundehepatitis geimpft. Als Kriterium der. Erkrankung wurde Temperatursteigerung, Leukopenie und Transaminasegehalt im Serum angewendet. Das Isolieren des Virus aus Urin als auch die Bestimmung der Antikörper im Serum wurde durchgeführt. Urologische Studien, unter anderem die Inulin- und PAH-clearance und anschliessend histologische Untersuchung der Nieren wurden vorgenommen. Es wurden infolge einer Virusinokulation keine Nierenveränderungen beobachtet.

Auf einem klinischen Material, bestehend aus 154 Hunden wurde zwischen dem Vorkommen von neutralisierenden bzw. komplementbindenden Antikörper gegen Virushepatitis der Hunde (HCC) und den Nierenschädigungen ein statistischer Vergleich unternommen. Von diesem Material hatten $64 \%$ neutralisierende Antikörper gegen HCC während mit der Komplementbindungsmethode waren es $51 \%$ positiv. Einen statistisch bemerkenswerten Zusammenhang zwischen Vorkommen von Antikörper gegen HCC und Nierenschädigungen konnte man nicht feststellen.

\section{SAMMANFATTNING}

Hcc-infektionernas etiologiska betydelse för hundens kroniska nefriter.

Inokulation av antikroppsfria hundar med hepatit-virus gjordes. Som kriterium på insjuknande användes temperaturstegring, leukopeni samt stegrad serumhalt av transamineringsenzym. Isolering av virus från urinen samt bestämning av antikroppshalten i blodserum utfördes. Urologiska studier bland annat omfattande inulin- och PAHclearance samt slutligen histologisk undersökning av njurarna företogs. Några njurförändringar uppkomna till följd av virusinokulationen kunde icke iakttagas.

På ett kliniskt material bestående av 154 hundar gjordes en statistisk jämförelse mellan förekomsten av neutraliserande antikroppar respektive komplementbindande antikroppar mot HCC och njurskador. Härvid framkom, att $64 \%$ av detta material hade neutraliserande antikroppar mot HCC, medan procenttalet positiva enligt komplementbindningsmetoden var $51 \%$. Något statistiskt signifikant samband mellan förekomsten av antikroppar mot HCC och njurskador kunde ej noteras. 